\title{
Corrigendum
}

Cold Spring Harb Protoc 2013; doi: 10.1101/pdb.prot070862

\section{Corrigendum: Purification of Oligodendrocyte Precursor Cells from Rat Cortices by Immunopanning}

Jason C. Dugas and Ben Emery

When this article was first published, the quantity and concentration of thyroid hormone (T3) in Step 1 of the recipe entitled "T3 Stock $(4 \mu \mathrm{g} / \mathrm{mL})$ " were incorrectly listed as $4 \mu \mathrm{g}$ and $0.8 \mu \mathrm{g} / 100 \mu \mathrm{L}$, respectively. The quantity of T3 should be $4 \mathrm{mg}$, and the concentration should be $0.8 \mathrm{mg} / 100 \mu \mathrm{L}$. The authors apologize for these errors. A corrected version of the recipe is below. In addition, the HTML version of the recipe (doi: 10.1101/pdb.rec075507) and the PDF version of the article have been amended accordingly.

\section{T3 Stock $(4 \mu g / m L)$}

1. Dissolve $4 \mathrm{mg}$ of thyroid hormone (T3; Sigma-Aldrich T6397) in $500 \mu \mathrm{L}$ of $1 \mathrm{~N} \mathrm{NaOH}$ to prepare a solution of $0.8 \mathrm{mg} / 100 \mu \mathrm{L}$.

2. Add $75 \mu \mathrm{L}$ of the T3 solution from Step 1 to $150 \mathrm{~mL}$ of Dulbecco's phosphate-buffered saline (DPBS; Invitrogen 14287-080).

3. Filter solution through a filter-sterilization unit, discarding the first $10 \mathrm{~mL}$.

4. Aliquot (e.g., $200 \mu \mathrm{L} /$ tube) and then store at $-20^{\circ} \mathrm{C}$.

(C) 2017 Cold Spring Harbor Laboratory Press

Cite this corrigendum as Cold Spring Harb Protoc; doi:10.1101/pdb.corr102947 


\section{Corrigendum: Purification of Oligodendrocyte Precursor Cells from Rat Cortices by Immunopanning}

Jason C. Dugas and Ben Emery

Cold Spring Harb Protoc; doi: 10.1101/pdb.corr102947

\begin{aligned} & $\begin{array}{r}\text { Email Alerting } \\ \text { Service }\end{array}$ Receive free email alerts when new articles cite this article - click here. \\ & \hline $\begin{array}{r}\text { Subject } \\ \text { Categories }\end{array}$ Browse articles on similar topics from Cold Spring Harbor Protocols. \\ & \hline\end{aligned}

